Fixed Point Theory, 22(2021), No. 2, 785-794

DOI: $10.24193 /$ fpt-ro.2021.2.51

http://www.math.ubbcluj.ro/ nodeacj/sfptcj.html

\title{
CARISTI'S AND DOWNING-KIRK'S FIXED POINT THEOREMS ON BIPOLAR METRIC SPACES
}

\author{
KÜBRA ÖZKAN*, UTKU GÜRDAL** AND ALİ MUTLU*** \\ *Manisa Celâl Bayar University, Department of Mathematics, 45140, Manisa, Turkey \\ E-mail: kubra.ozkan@hotmail.com \\ **B Burdur Mehmet Âkif Ersoy University, Department of Mathematics, 15030, Burdur, Turkey \\ E-mail: utkugurdal@gmail.com \\ (Corresponding author) \\ *** Manisa Celâl Bayar University, Department of Mathematics, 45140, Manisa, Turkey \\ E-mail: abgamutlu@gmail.com
}

\begin{abstract}
In this paper, we give some new fixed point results over bipolar metric spaces, that extend Caristi's and Downing-Kirk's fixed point theorems.

Key Words and Phrases: Bipolar metric space, fixed point, Caristi map, completeness.

2020 Mathematics Subject Classification: 54E50, 47H10, 54H25.
\end{abstract}

Acknowledgment. The authors would like to thank the referees for their careful review and insightful comments in relation to this work.

\section{REFERENCES}

[1] T. Abdeljawad, E. Karapınar, Quasicone metric spaces and generalizations of Caristi Kirk's theorem, Fixed Point Theory and Applications, (2009), doi:10.1155/2009/574387.

[2] Ö. Acar, İ Altun, S. Romaguera, Caristi's type mappings on complete partial metric spaces, Fixed Point Theory, 14(2013), no. 1, 3-10.

[3] A. Aghajani, R. Allahyari, Fixed-point theorems for multivalued generalized nonlinear contractive maps in partial metric spaces, Ukrainian Mathematical Journal, 66(2014), no. 1, 1-15.

[4] C. Alaca, M.E. Ege, C. Park, Fixed point results for modular ultrametric spaces, Journal of Computational Analysis and Applications, 20(7)(2016), 1259-1267.

[5] M.R. Alfuraidan, M.A. Khamsi, Caristi fixed point theorem in metric spaces with a graph, Abstract and Applied Analysis, (2014), Article ID: 303484.

[6] İ Altun, G. Minak, An extension of Assad-Kirk's fixed point theorem for multivalued nonself mappings, Carpathian Journal of Mathematics, 32(2016), no. 2, 147-155.

[7] B.C. Ampadu, Some fixed point theory results for convex Reich contraction mapping of order 2, Journal of Fixed Point Theory and Applications, 13(2018), 1-42.

[8] A. Arunchai, S. Plubtieng, Caristi's random fixed point theorem for generalized distance on Polish spaces, Carpathian Journal of Mathematics, 32(2016), no. 3, 285-292.

[9] V. Berinde, I.A. Rus, Caristi-Browder operator theory in distance spaces, In: Alfuraidan M.R., Ansari Q.H. (eds), Fixed Point Theory and Graph Theory, Elsevier, 2016, 1-28. 
[10] J. Caristi, Fixed point theorems for mappings satisfying inwardness conditions, Transactions of the American Mathematical Society, 215(1976), 241-251.

[11] M.M. Choban, Fixed points for mappings defined on pseudometric spaces, Creative Mathematics and Informatics, 22(2013), no. 2, 173-184.

[12] L. Ćirić, Fixed point theorems for multi-valued contractions in complete metric spaces, Journal of Mathematical Analysis and Applications, 348(2008), no. 1, 499-507.

[13] M.O. Diallo, M. Oudadess, Extentions of Caristi-Kirk's Theorem, Turk. J. Math., 20(1996), no. $2,153-158$

[14] D. Downing, W.A. Kirk, A generalization of Caristi's theorem with applications to nonlinear mapping theory, Pacific Journal of Mathematics, 69(1977), no. 2, 339-346.

[15] A.D. Filip, A. Petruşel, Fixed point theorems for operators in generalized Kasahara spaces, Revista de la Real Academia de Ciencias Exactas, Fisicas y Naturales, Serie A, Matematicas, 109(2015), no. 1, 15-26.

[16] A. Gupta, G.K. Soni, Generalized coupled fixed point theorems on bipolar metric spaces, International Journal of Mathematical Archive, 10(4)(2019), 1-8.

[17] E. Karapınar, Generalizations of Caristi Kirk's theorem on partial metric spaces, Fixed Point Theory and Applications, (2011), doi:10.1186/1687-1812-2011-4.

[18] W.A. Kirk, Caristi's fixed point theorem and metric convexity, Colloquium Mathematicum, 36(1976), no. 1, 81-86.

[19] G.N.V. Kishore, R.P. Agarwal, B.S. Rao, R.S. Rao, Caristi type cyclic contraction and common fixed point theorems in bipolar metric spaces with applications, Fixed Point Theory and Applications, 21(2018), no. 1, 1-13.

[20] G.N.V. Kishore, K.P.R. Rao, A. Sombabu, R.V.N.S. Rao, Related results to hybrid pair of mappings and applications in bipolar metric spaces, Journal of Mathematics, (2019), doi:10.1155/2019/8485412.

[21] T.A. Lazăr, A. Petruşel, N. Shahzad, Fixed points for non-self operators and domain invariance theorems, Nonlinear Analysis: Theory, Methods \& Applications, 70(2009), no. 1, 117-125.

[22] A. Mutlu, U. Gürdal, Bipolar metric spaces and some fixed point theorems, The Journal of Nonlinear Science and Applications, 9(2016), 5362-5373.

[23] A. Mutlu, K. Özkan, U. Gürdal, Coupled fixed point theorems on bipolar metric spaces, European Journal of Pure and Applied Mathematics, 10(4)(2017), 655-667.

[24] A. Mutlu, K. Özkan, U. Gürdal, Fixed point theorems for multivalued mappings on bipolar metric spaces, Fixed Point Theory (in press).

[25] K. Özkan, U. Gürdal, A. Mutlu, A generalization of Amini-Harandi's fixed point theorem with an application to nonlinear mapping theory, Fixed Point Theory (in press).

[26] A. Petruşel, G. Petruşel, Selection theorems for multivalued generalized contractions, Mathematica Moravica, 9(2005), 43-52.

[27] B.S. Rao, G.N.V. Kishore, D. Rampasad, Some tripled fixed point theorems in bipolar metric spaces, International Journal of Management, Technology and Engineering, 9(2019), no. 1, 715727.

[28] S. Romaguera, A Kirk type characterization of completeness for partial metric spaces, Fixed Point Theory and Applications, (2009), doi:10.1155/2010/493298.

[29] N. Shioji, T. Suziki, W. Takahashi, Contractive mappings, Kannan mappings and metric completeness, Proceedings of the American Mathematical Society, 126(1998), no. 1, 3117-3124.

Received: March 14, 2019; Accepted: August 28, 2019. 
